\title{
'Agents-in-Focus' and 'Agents-in-Context': the Strong Structuration Analysis of Central Government Accounting Practices and Reforms in Nepal
}

\author{
Pawan Adhikari and Kelum Jayasinghe \\ Essex Business School, University of Essex
}

\begin{abstract}
Drawing on Stones' (2005) strong structuration theory, the paper unfolds why and how the key stakeholders of central government accounting in Nepal are involved in the reproduction of routinised accounting practices, resisting the externally-propagated changes. Government accountants (the agents-in-focus) through their capability to control the budget routines have enjoyed a powerful social position in their position-practice relations with the agents-incontext, i.e. professional accountants and international consultants, higher-level officers and administrators, auditors, and politicians. Social position along with historically-imbued dispositions and their conduct and context analysis have enabled government accountants to strategically exercise their agency. Government accountants have articulated duality and a dialectic relation with the agents-in-context, which have resulted in the reproduction of everyday accounting practice and the resistance to the World Bank-led reforms, such as accrual accounting and, more recently, the Cash-Basis IPSAS.
\end{abstract}

Keywords: Strong structuration theory; Emerging economies; Government accounting; Nepal.

\section{Introduction}

This paper is meant to generate a nuanced insight into central government accounting practices and reforms in emerging economies. In particular, using Stones' (2005) strong structuration theory (SST) as a sensitising device, we have striven to investigate 'why' and 'how' the key internal stakeholders of central government accounting in Nepal, including government and professional accountants, higher-level officers and administrators, international consultants, politicians, and auditors, are involved in the reproduction of routinised accounting practices, resisting the externally-propagated changes. We have given special attention to government accountants (the agents-in-focus) at different levels of 
Nepalese administration who share similarities in agency and structures, given their central role in mediating accounting practices and changes within the networks of relationships. Prior work on government accounting and budgeting in Nepal (Adhikari, Kuruppu, \& Matilal, 2013; Adhikari \& Mellemvik, 2011), as well as in other emerging economies (Harun, Peursen, \& Eggleton, 2012; Goddard, Assad, Issa, \& Malagila, 2016; Lassou \& Hopper, 2016; Neu, Everett, \& Rahaman, 2009), has given much attention to international monetary organisations, mainly the World Bank and the International Monetary Fund (IMF), and the institutional pressures that these organisations have exerted to instigate reforms. These organisations, through their lending activities, technical assistance, and reports on best practices, have created a perception that government accounting practice in emerging economies is deficient, resulting in weak governance, accountability, and economy (Rahaman \& Lawrence, 2001; Rahaman, 2010; Hopper, Lassou, \& Soobaroyen, 2016). Therefore, government accounting reforms lay at the heart of their development discourses about these economies, which they argue would be achieved by adopting certain neo-liberal measures advocated by the New Public Management (NPM) and the New Public Financial Management (NPFM) (Hood, 1995; Guthrie, Olson, \& Humphrey, 1999); for instance, accrual accounting, participatory budgeting, and International Public Sector Accounting Standards (IPSASs) (Neu \& OCampo, 2007; Van Helden \& Uddin, 2016; Kuruppu et al., 2016).

The experience of many emerging economies which have, in recent years, undertaken reforms in government accounting delineates that such changes have often been overshadowed by unintended consequences and failures (Uddin, Gumb, \& Kasumba, 2011; Goddard et al., 2016). In some emerging economies, reforms have been abandoned as they have turned out to be difficult to implement, and, in other cases, they have been adopted but not put into practice or proved to be dysfunctional (Andrews, 2012; Adhikari et al., 2013; Hopper et al., 2016). For instance, Lassou and Hopper (2016) have in their study of a country in Francophone Africa illustrated how a locally-developed government accounting system, widely regarded as effective, was abandoned for a French system, which later turned out to be problematic in practice. That government accounting reforms have become more a means for emerging economies to secure legitimacy at the institutional level rather than for improving the existing practice is evident in the extant literature (Adhikari \& Mellemvik, 2011; Harun et al., 2012; Neu et al., 2009). Several reasons have been cited for the failure of the ceremonial adoption of externally-proposed government accounting reforms in emerging 
economies, primarily inadequate planning; poorly grounded reform recipes, i.e. the adoption of the one-size-fit approach; a lack of human resources and IT systems; and the intervention of consultants (Allen, 2011; Van Helden \& Uddin, 2016; Van Helden \& Ouda, 2016). Corruption has become another dominant factor in recent years making government accounting reforms in emerging economies expensive and dysfunctional (Goddard et al., 2016; Uddin et al., 2011).

With few exceptions (Jack \& Kholeif, 2008; Uddin \& Tsamenyi, 2005), the issues of organisational actors (agency) at the ontic (micro) level and the influence that these actors can have in making public sector accounting reforms in emerging economies a success or a failure have drawn less attention in the literature. For instance, Uddin \& Tsamenyi (2005) have in their case study of budgetary and other public sector reforms in a Ghanaian state enterprise illustrated why such changes were politicised and delayed by internal actors, thereby making them unable to serve public interests. In a similar vein, Jack \& Kholeif (2008) have investigated the implementation and use of Enterprise Resource Planning, an information technology system, in an organisation in Egypt, and reported an exploration of conflicting beliefs about the role of management accountants. Studies have delineated that organisational actors resist the proposed accounting changes that are incompatible with the existing practices and structures (Nor-Aziah \& Scapens, 2007; Englund et al., 2011; Scapens \& Roberts, 1993). Such changes lead to structural contradictions and pose organisational actors with a threat in pursuing their interests and exercising their power relationships (Ashraf \& Uddin, 2015). Organisational actors, therefore, tend to maintain the status quo so that their vested power and interests are not affected by the outcomes of the reforms.

However, there remains a paucity of research addressing how government accounting permeates day-day-day work and the role of active agency and structures in facilitating accounting practices and resisting changes. By looking at the central government accounting of Nepal, this study aims to make a contribution to the substance of this debate. A striking aspect of Nepalese government accounting has been the stability of cash accounting, despite several endeavours over the last five decades to implement reforms such as accrual accounting and programme budgeting, and, more recently, the Cash-Basis International Public Sector Accounting Standard (IPSAS) (Adhikari et al., 2013). This stability in accounting has resulted in the Nepalese central government being a prominent research 
setting to explore the role of agency and structures, factors which play a key role in executing accounting practices and changes (Adhikari \& Mellemvik, 2011).

As mentioned earlier, we have drawn on Stones' (2005) SST as a sensitising device to investigate why and how the key internal stakeholders of Nepalese government accounting are involved in the reproduction of routinised accounting practices and resisting changes. The SST is claimed to be the strengthened version of structuration theory contributing to the extension of knowledge assembled by prior Giddensian work, which is focused on the duality between agents and abstract structures, i.e. significance, legitimation, and domination, through the combination of the external and internal aspects of structures (Coad, Jack, \& Kholeif, 2015, 2016; Harris, Northcott, Elmassri, \& Huikku, 2016). The SST-based accounting literature argues that the theory has helped accounting researchers overcome the Giddens flat and abstract ontology and promote empirical case studies of particular agents and structures, where the agents are embedded in a network of position-practice relations at different ontological scale (Coad \& Glyptis, 2014; Elmassri, Harris, \& Carter, 2016; Feeney \& Pierce, 2016). Coad et al., (2015) state that another strength of strong structuration theory (SST) lies in its potential for effective research design for empirical studies so as to generate more meaningful insight into the way accounting is implicated in everyday organisational life. We argue that the use of SST in this study enables us to focus more on agency and outcomes, and to engender a comprehensive understanding of day-to-day government accounting practices and reforms in Nepal by unfolding the position-practices of government accountants (the agents-in-focus) and their capability of articulating duality and a dialectic of relations with other agents (the agents-in-context).

The remainder of this paper is organised as follows. In section 2, we discuss Stones' SST and its relevance in the study of government accounting practices and reforms in Nepal. The research method is outlined in section 3. Section 4 offers a brief overview of the evolution of Nepalese public administration and government accounting, and sheds light on the day-to-day government accounting practices and the changes proposed. We present our empirical findings in Section 5, analysing the social position (external structures) and internal structures of government accountants and their agency. The section also demonstrates the multiple dialectics of control taking place between government accountants and other agents (the agents-in-context), generating resistance to reforms. The final section summarises Nepalese 
government accounting practices and changes in the light of SST, and offers some concluding remarks highlighting the major contributions of the study.

\section{Strong structuration theory in accounting research}

The use of Giddens' $(1979,1984)$ structuration theory (ST) has not been a new tradition in interpretive accounting research (see e.g. Englund \& Gerdin, 2014). ST concerns the interactions between agency and structures. The latter are memory traces embedded in the minds of agents in the form of rules and resources. Giddens $(1979,1984)$ has applied the term 'structural modalities' to incorporate three different types of abstract structures, i.e. significance (interpretative schemes), legitimation (norms which sanction certain forms of conduct), and domination (the exercise of power), which the actors instantiate when they interact with others, and which either enable or constrain their action. Every action therefore involves agency and the instantiation of structures forming a duality (Englund et al., 2011; Macintosh and Scapens, 1990). Prior structuration-based accounting studies have illustrated how this understanding of duality has helped scholars conceptualise accounting as an organisational and social practice and theorise both accounting continuity and change (Englund, Gerdin, \& Burns, 2011). Although the use of ST is more evident within the domain of management accounting in private enterprises (Englund and Gerdin, 2014), public sector accounting researchers have drawn on the theory to explore reforms taking place, mainly in western countries (Conrad, 2005; Seal \& Ball, 2011; Moore, 2013; Lawrence, Alam, Northcott, \& Lowe, 1997), as well as in emerging economies (Uddin \& Tsamenyi, 2005).

ST is not, however, without criticism and certain elements of the theory are claimed to be underdeveloped (Stones, 2005; Stones \& Jack, 2016; Coad et al., 2015; Coad et al., 2016; Greenhalgh, Stones, \& Swinglehurst, 2014). Englund et al. (2011) state that this is perhaps not surprising as Giddens himself (1984, p. 327) has stated that "the concepts of ST should for many research purposes be regarded as sensitizing devices, nothing more". Critics of ST mainly focused on the fact that there is an overemphasis on the relatively abstract (macrolevel) analysis of the structures of signification, legitimation, and domination, as well as the adoption of high-level institutional analysis, often neglecting the role of agency in the duality of structure (Coad et al., 2015; Harris et al., 2016; Makrygisnnakis \& Jack, 2016). More importantly, the role of external structure, which is represented by position-practice relations and which plays a central role in the conceptualisation of the link between structures and 
agencies at the meso and ontic levels, has been claimed to have been downplayed both in the theory and in the extant structuration-based accounting literature (Stones, 2005; Cohen, 1989). The majority of ST-inspired studies have therefore appeared weak in terms of empirically revealing the impact of power embedded in 'structure-agent' relationships (Elamassri et al., 20160) and of explaining 'how' knowledgeable agents draw upon and reproduce the structures (accounting structures) in specific settings (Conrad, 2005; Englund et al., 2011). The need to exploit structuration theory's full potential by unfolding how agency is implicated in the structuration process is called on in recent studies (Englund \& Gerdin, 2014).

The emergence of strong structuration theory (SST) (Stones, 2005) is envisaged as an attempt to address some of these perceived limitations of Giddens' structuration theory and to offer a new lease of life to the structuration process (Coad et al., 2015; Stones \& Jack, 2016). Accounting studies drawing on the SST have significantly increased in recent years covering areas and events as diverse as strategic investment decision-making (SIDM) (Elmassri et al., 2016), the implementation of an information technology system (Jack \& Kholeif, 2008), new product development (Feeney \& Pierce, 2016), the 2008 financial crisis (Makrygiannakis \& Jack, 2016), carbon pricing (Moore \& McPhail, 2014), and power struggles between engineers and accountants (Coad \& Herbert, 2009). Harris et al. (2016) have argued in their reanalysis of four cases of SIDM - which were previously drawn from other theories, for instance grounded, actor-network, practice and personal construct theories - that SST is better suited than those other theories in terms of unfolding complex processes of human interaction and of generating additional insights into SIDM. In recent SST-based studies, a call has been made for the use of theory in the specific settings of emerging economies, predicating its potential usefulness in offering an understanding of externally-proposed accounting reforms and the challenges that these reforms may face in the process of implementation (Coad et al., 2015). The public sector is especially emphasised given the existence of multiple stakeholders who are situated within a web of position-practice relations at varied ontological scales, and who have some sort of interest in day-to-day accounting practice (Coad et al., 2016). In this paper, we have attempted to address this concern through a study of government accounting practices and reforms in Nepal.

The SST emphasises that an understanding of a particular social phenomenon in a particular time and place can only be achieved by focusing on the 'in-situ' process of structuration and 
undertaking empirical studies of particular agents and structures at the ontic level - the level at which empirical can be sought (Stones, 2005; Harris et al., 2016; Coad et al., 2016). A key aspect of SST, which differentiates it from Giddens' structuration theory, has been its endeavour to bring the role of agency to the foreground of the structuration process through the agents' conduct and context analysis (Coad et al., 2015). This is also claimed to be an attempt at rectifying the limitations of Giddens' methodological bracketing. However, Stones (2005) states that this requires researchers to pay particular attention to research design by first locating the agents-in-focus and identifying and analysing their structures. Although the duality of structure has remained at the heart of SST, Stones (2005) asserts that duality is best understood through analysis of a quadripartite framework, which consists of four analytically-distinct components consisting external structures, internal structures within the agents, active agency, and outcomes.

External structures - the first component of the quadripartite framework - provide the agents with their conditions of action. The external structures are mediated largely through positionpractices (Stones, 2005). A position-practice is a social position, its associated identity and practice, and the network of social relations that constitute various institutional reciprocities and asymmetric power relations (Greenhalgh \& Stones, 2010). Coad et al. (2015) state that the way Stones has conceptualised 'position' can be reconciled with the idea of Giddens (1984) in that it provides an incumbent actor with a social identity with a range of prerogatives, capabilities, resources, norms, and obligations. Position-practices are enacted and perpetuated by active agents within the network of relationships. An understanding of position-practice relations therefore enables the researchers to tease out how different actors battle against others to gain and maintain legitimacy. For instance, Coad \& Glyptis (2014) have deployed a position-practice perspective with its four interrelated elements, i.e. praxis, positioning, capabilities, and trust, to unfold the management and control of a joint venture between companies engaged in the production and shipment of oil and petroleum products.

Greenhalgh \& Stones (2010, p. 70) mention that during the structuration process, the agents draw upon their internal structures which are further analytically divided into general dispositions (i.e. socio-cultural schemas, discourses and world-views, moral principles, attitudes, ambitions, skills, and personal value commitments) and conjuncturally-specific knowledge of the strategic terrain and 'how one is expected to act within it, based on one's hermeneutic understanding of external structures'. Active agency implies the way in which 
agents draw on their internal structures and use their knowledge and understanding of external structures (Coad \& Herbert, 2009). Stones (2005) states that the agents' knowledge of how they might be expected to act and of the rewards and sanctions likely to follow from their actions correspond to Giddens's widely cited (but highly abstract) terminologies: interpretative schemas (structures of signification), normative expectations (structures of legitimation), and a capability to mobilise authority and resources (structures of domination). The last element of the quadripartite framework, i.e. outcomes, can be intended or unintended feedback on both external and internal structures, either preserving them faithfully or changing them as they are enacted (Greenhalgh \& Stones 2010; Coad et al., 2015).

That SST has provided additional insights into active agency in the duality and outcomes are evident in recent work (Moore \& McPhail, 2016; Feeney \& Pierce, 2016; Elmassri et al., 2016; Makrygiannakis \& Jack, 2016). However, Coad et al., (2016) state that accounting researchers are yet to fully exploit the potential of SST by moving beyond an overly static use of the quadripartite framework to the agent's conduct and context analysis. It is argued that such an analysis would help researchers to explore the relational power of agent positionpractice and better interpret the dialectics of control (Harris et al., 2016). The present study therefore adds to the existing SST-based accounting literature by focusing on government accountants (the agents-in-focus) and bringing out their perceptions and understanding of other agents in the articulation of a dialectic relationship. Given the fact that government accounting in Nepal has remained stable in the last five decades, we have paid more attention to unfolding the dialectic of control in terms of resistance.

Jack \& Kholeif (2008) argue that by conceptualising position-practice relationships, external structures as a condition of action, and the ability of agents to do otherwise and unintended consequences, SST has offered a renewed way of interpreting the dialectic of control in terms of resistance. In his strong structuration theory, Stones (2005) has clarified that for generating a resistance, the agents (the agents-in-focus) must possess three types of property, which include perceived power or capability in relation to other actors, adequate knowledge of relevant external structures, including alternative avenues of possibility, and an ability to gain requisite reflective distance from their conditions of action. The extent to which the agent possesses these three properties, if all other things remain equal, determines his or her ability to regulate, modulate, reflect, and erase specific aspects of external demands and pressures. With the exception of Jack \& Kholeif (2008), we are not aware of any studies in accounting 
that have empirically applied the dialectic of control in terms of resistance to investigate the ways in which accounting practices are reproduced, rejecting the external requirements and pressures for articulating changes. This has been another area within SST where the contribution of prior work is limited (Harris et al., 2016). In this regard, the use of SST is valuable in our study not only to generate a nuanced picture of everyday government accounting in Nepal at the ontic level, but also to theorise how the resistance to externallypropagated changes is being executed in the dialectic relationships. In addition, the present study responds to the call that the recent SST-based studies have made to further extend the emerging stream of SST by empirically unpacking both the reasons and manners through which the stability in accounting practice is maintained in emerging economies (Coad et al., 2016; Coad et al., 2015).

\section{Research method}

Our research design reflects what Pawson \& Tilley (1997) and Makrygiannakis \& Jack (2016) have mentioned as a 'circular design' in that we have applied the SST to explore dayto-day government accounting in Nepal at the ontic level, and at the same time striven to further extend an element of theory (i.e. the dialectic of control in term of resistance) using the empirical data. The data for the study are derived from two main sources: document analysis and semi-structured interviews. Initially, we reviewed the main normative sources articulating day-to-day government accounting practices and regulating government accountants, i.e. the 2007 Financial Procedures Rules (FPR), the 1999 Financial Administration Rules (FAR), and the 1993 Civil Service Rules (CSR) (with the third amendment of 2011) (Government of Nepal, 1999; 2007; 2011). At the next stage, we reviewed reports issued by government agencies and international organisations discussing various aspects of Nepalese central government accounting practice and recommending changes. This initial documentary analysis helped us not only generate an understanding of Nepalese government accounting norms and practices, ongoing changes, and the positionpractices of government accountants and other stakeholders, but also construct a necessary background for selecting our interviewees.

As stated earlier, the SST advocates the design of research data collection through the agent's conduct and context analysis (Coad et al., 2015 and 2016). While the former examines an agent's internal knowledgeability based on disposition and conjuncture, the latter is meant for 
the analysis of an agent's external terrain and institutional position-practices (Stones, 2005). The SST is predicated on the assumption that the combination of context and conduct analysis enables accounting researchers to explore the interaction between the external terrain and the agent's internal knowledgeability, an understanding of which is reckoned to be paramount to engender insights into everyday accounting practices (Feeney \& Pierce, 2016). The identification of agents, both the agents-in-focus and agents-in-context, is therefore reckoned to be an initial step while drawing on the SST. Government accountants at different hierarchies are our 'agents-in-focus', given that they are the key players in the articulation of accounting practices and changes. The criterion for selecting government accountants for the interviews has been either their experience in everyday accounting practices or their involvement in the negotiation and implementation of accounting changes. One of the authors' previous employments in a Nepalese government entity, as well as his engagement with government accounting as a consultant, proved valuable in the establishment of initial contacts with some government accountants, who, in turn, helped us gain access to other accountants, as well as the agents-in-context. In particular, government accountants we interviewed included joint comptrollers (first-class or higher-level officers/administrators), senior and junior government accountants (i.e. gazetted or officer-level accountants), and non-gazetted government accountants (i.e. non-officer level accountants) at the Financial Comptroller General Office (FCGO) and the Financial Administration Division (FAD) of various ministries (mainly the Ministry of Health $(\mathrm{MoH})$, the Ministry of Education $(\mathrm{MoE})$, and the Ministry of Federal Affairs and Local Development (MoFALD)).

The SST states that an agent's understanding of conditions of action is informed by the conjuncturally-specific knowledge of networked others (Stones, 2005). This also manifests that interviews with other stakeholders (the agents-in-context) are equally important so as to generate a depth of the structuration process surrounding the agents-in-focus (Harris et al., 2016). The agents-in-contexts' ability to influence the hermeneutic frames and strategic conduct of the agents-in-focus are also reckoned to be evidence of the dialectic of control. Our agents-in-context in the present study include joint secretaries (first-class or higher-level officers/administrators) and officers (administrators/under-secretaries/bureaucrats) at the Ministry of Finance (MoF) and the above-mentioned ministries; senior and junior auditors at the Auditor General's Office (AGO); and professional accountants (chartered accountants) at the Institute of Chartered Accountants of Nepal (ICAN) and the Accounting Standards Board 
(ASB), some of whom had also served in the past as a consultant of international organisations (see Appendix A).

One of the authors visited Kathmandu, Nepal, during March/April 2014 and conducted 40 semi-structured interviews. The interviews conducted in the Nepalese language lasted an average of an hour and a half with each participant. All interviews were recorded and subsequently transcribed. Government accounting in emerging countries is conceived of as being a politically sensitive area given that it deals with governments' incomes and expenses and the way accountability is discharged (Adhikari \& Mellemvik, 2011; Lassou \& Hopper, 2016). Recognising the political sensitivity of the topic, government accountants, as well as other stakeholders of government accounting, are often hesitant to answer the structured questions due to fear and a lack of trust (Adhikari et al., 2013). Having realised this, we assured our interviewees prior to the interviews that their anonymity would be maintained. Next, we started our interviews both to the agents-in-focus and the agents-in-context by presenting open-ended questions raising concerns over their social position, prerogatives, and obligations; objectives and purposes of government accounting; day-to-day government accounting practices and reforms; and the interactions between them in facilitating day-today accounting practices and implementing reforms. We articulated interviews more as freeflowing conversations allowing respondents to focus on any aspect(s) within the issues we raised to them. However, based on the feedback and the engagement of the informants, we attempted to be more specific as the interviews flowed. For instance, we raised concerns particularly to government accountants (the agents-in-focus) about how they perceive and understand everyday accounting practice (knowledgeability) and the basis of their active agency. This helped us to conceptualise their internal knowledgeability and awareness of their external terrain, both of which we argue were paramount in elucidating why accounting is produced and reproduced in everyday life. We also discussed both with government accountants and the agents-in-context their preference and priority in government accounting, the way they interact with each other, and the extent they are aware of the conduct and context of each other, as part of understanding how they are articulating the duality and dialectic relationships.

We had the opportunity to reinterview five government accountants during our data collection for another project in Kathmandu in August 2015 (Appendix A). We used these interviews to clarify issues that had remained ambivalent during our first round of interviews, 
as well as to ensure the reliability and validity of our findings. At the final stage, we analysed our data using the 'template analysis' (King, Murray, Salomon, \& Tandon, 2004). We noted down the views and issues frequently expressed by our interviewees. Attempts were made to match them with the evidence gathered through the literature search. We then developed a list of codes (or a template) representing the four elements of the quadripartite framework. The data representing the themes were then clustered. At the next stage, we endeavoured to establish a link between the themes so as to create narratives, the significance of which is particularly emphasised in the examination of structure and agency (Pozzebon \& Pinsonneault, 2005). As stated by Jack \& Kholeif (2008), we have presented our case in a narrative form interpreting the day-to-day practices of government accountants and the network of relationships between them and other administrators at different hierarchies, auditors, consultants, politicians, and professional accounting leading to a situation of duality, dialectics, and resistance.

\section{The Nepalese government accounting context, practice, and reforms}

Public sector organisations are operating differently in emerging countries due to their unique historical, cultural, and political circumstances (Alawattage, Hooper, \& Wickramasinghe, 2007). Such circumstances have a profound impact on the way accounting is implicated in everyday life and the reforms are articulated (Van Helden \& Uddin, 2016). Adhikari \& Mellemvik (2009) argue that Nepalese public administration and accounting have been structured distinctly and more traditionally, as compared with many other emerging economies, due to Nepal's non-colonial history. In the following two sub-sections, we discuss the evolution of public administration and government accounting in Nepal and shed light on the day-to-day government accounting practices and the changes proposed over time.

\subsection{Public administration, bureaucracy and government accounting in the context of dictatorship and political patronage}

Nepal was established as a country in 1769 with the unification of more than 50 small scattered kingdoms. The country was under the family dictatorship of Ranas (one of the castes in Nepal) from 1846 until 1950. The Rana rulers had maintained stringent control in public administration, and any defaults in public funds or errors in accounting were the responsibility, not only of the defaulters, but also of their heirs up to the seventh generation 
(Gongal, 1973). The control mechanisms imposed by the Rana rulers had led the administrators and accountants to live and perform under fear. They tended to shift their personal responsibilities to others, mainly to higher-level officers, and avoided undertaking any decisions that might have repercussions to their positions for the sake of their family members' security (Dix, 2011).

Nepalese scholars have mentioned that the country was in a medieval era when it was liberated from the Rana families in 1950 (Shrestha, 1965; Joshi, 1973). While other neighbouring countries, for instance, India and Sri Lanka, who had been under the British Empire, as well as other colonies in Asia, for instance, Cambodia and Fiji, had already established an accounting profession, board, and system (Verma \& Gray, 2009; Wijewardena \& Yapa, 1998; Yapa, Jacobs, \& Huot, 2016), Nepal was without any state institutions such as ministries, governance tools (for example, the budget and accounting systems), and the regulations for recruiting administrators and accountants (Adhikari et al., 2013; Goodall, 1963, 1975). Rose \& Landau (1977) state that a dearth of resources, both technical and human, and infrastructure led Nepal to become dependent on international organisations and development agencies much earlier than many emerging or neighbouring countries in pursuing its development and modernisation initiatives.

During the first few years of the 1950s, Indian advisors helped Nepal to set up state institutions such as ministries and the Public Service Commission (PSC) (Joshi, 1973). Adhikari \& Mellemvik (2009) state that the United Nations (UN) and the United States Agency for International Development (USAID) had prioritised government accounting changes to track the progress of development expenditures, which they had offered in the form of grants and aid. In 1962, cash accounting was introduced in the country with the financial and technical assistance of these two organisations (Chatterjee, 1967). Sharma (1996) mentions that government accounting was, however, recognised as a separate discipline in Nepal only after the establishment of the FCGO in 1974. The FCGO was provided with the status of an independent organ for government accounting and was delegated all accounting-related tasks that were previously handled by the Ministry of Finance (MoF); for instance, disbursing budget to all spending entities, conducting internal audits, tracking foreign aid, grants, and loans, and consolidating the accounting statements. The office was termed the 'District Treasury Comptroller Office' (DTCO) at the district levels (Sharma, 2002). 
The operation of the FCGO had a profound impact on the position-practices of government accountants and setting up their conjuncturally-specific knowledge and active agency. Government accountants were then separated from other administrators and brought under the jurisdiction of the FCGO (Agrawal \& Bista, 1981). In this way, a distinct accounting group was constructed within the FCGO accommodating government accountants who were at different levels, i.e. gazetted level (officer-level) and non-gazetted level (non-officer level), and in different hierarchies. This organisation and classification of government accountants still prevails in the country today (PSC, 2007). There are two hierarchies within the gazettedlevel accountants, i.e. senior and junior accountants, and the non-gazetted accountants are ranked as first-, second-, third-, and fourth-class accountants. The Public Service Commission (PSC) is an assigned body to recruit government accountants at all these levels. An undergraduate degree in any of the three disciplines of commerce, accounting, or economics is a minimum requisite for the senior and junior accountants. The non-gazetted accountants are required to complete their higher secondary school education. More interestingly, government accountants are prohibited to leave the group and alter their position until and unless they are promoted to a first-class officer (a higher-level officer/administrator), a topmost position in Nepalese pubic administration (GoN, 2015). The fact that government accountants are often confined to their own group (i.e. social system) with distinct social positions (i.e. budget executers/controllers) has led to the development of a high degree of trust (social capital) between them, which is, in the strong structurationinspired literature, reckoned to be a constitutive aspect of position-practice relations (Coad \& Glyptis, 2014; Moore \& McPhail, 2016).

Nepalese scholars argue that the administrative culture founded on the Ranas' feudal traditions, and its key features such as risk aversion, decision avoidance and red-tapism has continued to dominate the general dispositions and agency of Nepalese government accountants and administrators (Hachhethu, 2009; Acarya, 2011; Shakya, 2009). Mentions are made that the new government appointees tend to adjust their actions to underpin such established dispositions and taken-for-granted routines rather than exert any efforts to alter or modify them (Dhakal, 2007; Pokharel, 2011). Since the restoration of democracy in 1990, the operation of public administration has been further exacerbated due to over-politicisation. All issues relating to the appointment and promotion of administrators and accountants are now based on their proximity to political parties and their sister trade organisations (Pokharel, 
2011; Acharya, 2011). Furthermore, a low pay scale and rampant political corruption have resulted in the erosion of morale and innovativeness in the Nepalese public administration (Dix, 2011; World Bank, 2002). Claims have been made that the Nepalese administrators and accountants have become even more conservative than the citizens and politicians, and that the implementation of many administrative reforms have turned out to be futile given their concerns over maintaining the status quo (Shakya, 2009; Dix, 2011; Pokharel, 2013). The historical and structural construction of active agency is therefore reckoned to be different in Nepal compared to many other emerging economies.

\subsection{Government accounting practices and proposed reforms}

Adhikari et al. (2013) argue that the fundamental objective of Nepalese government accounting and the way government accountants are structured and mobilised have remained intact over the last few decades. Recent changes that have occurred in government accounting are confined to extending the regulations rather than putting those rules into practice. There are now new provisions annexed to the regulations for cost estimation, asset registration, and result demonstration. The main concern of government entities has been to execute the budget and maintain budgetary limits, as set out by their ministries concerned and the Ministry of Finance (MoF). Rewards and sanctions to government accountants are based on their capacity to spend the allocated budget and control overspending (World Bank, 2002; GoN, 2011, 2015). The prevailing hierarchical structure for government accounting in which government entities are scrutinised and consolidated at different levels is, for instance, an indication of the emphasis being placed on budget execution and control (Adhikari \& Mellemvik, 2011).

In practice, Nepalese central government accounting includes three levels: operating-, central-, and district-level accounting (see Figure 1). Each government entity entitled to budgetary support is required to furnish operating-level accounting, which commences by preparing the journal vouchers and ledgers, primarily the cash book and the budget sheet. Government entities are required to forward their monthly and annual accounts to the respective departments, line ministries, and district treasuries (DTCOs). The next level is central-level accounting for ministries and departments. These central-level agencies are required to examine the allocated budget and accounts of their subordinate entities and prepare a ministerial-level consolidated statement. It is, however, claimed that the 
significance of central-level accounting has continually withered since the operation of the DTCOs (World Bank, 2002). The fact that the DTCOs are authorised to release budget allocations to spending units within their jurisdictions has weakened the line ministries' capacity to exercise control over their subordinated units, and, in many cases, they only receive an annual report from their subordinated units, even though the regulations require the spending units to forward both the monthly and annual budget reports to their line ministries. Along with the ministries, the district treasuries (DTCOs) are required to maintain district-level accounting, which is concerned with collecting monthly accounts of spending units under their jurisdiction, facilitating internal auditing, and preparing monthly and annual consolidated statements for the district as a whole. Such district statements are to be forwarded to the FCGO and line ministries on a monthly and annual basis. Figure 1 depicts the day-to-day government accounting practices in the Nepalese central government.

Figure 1: Government accounting practice in Nepal 


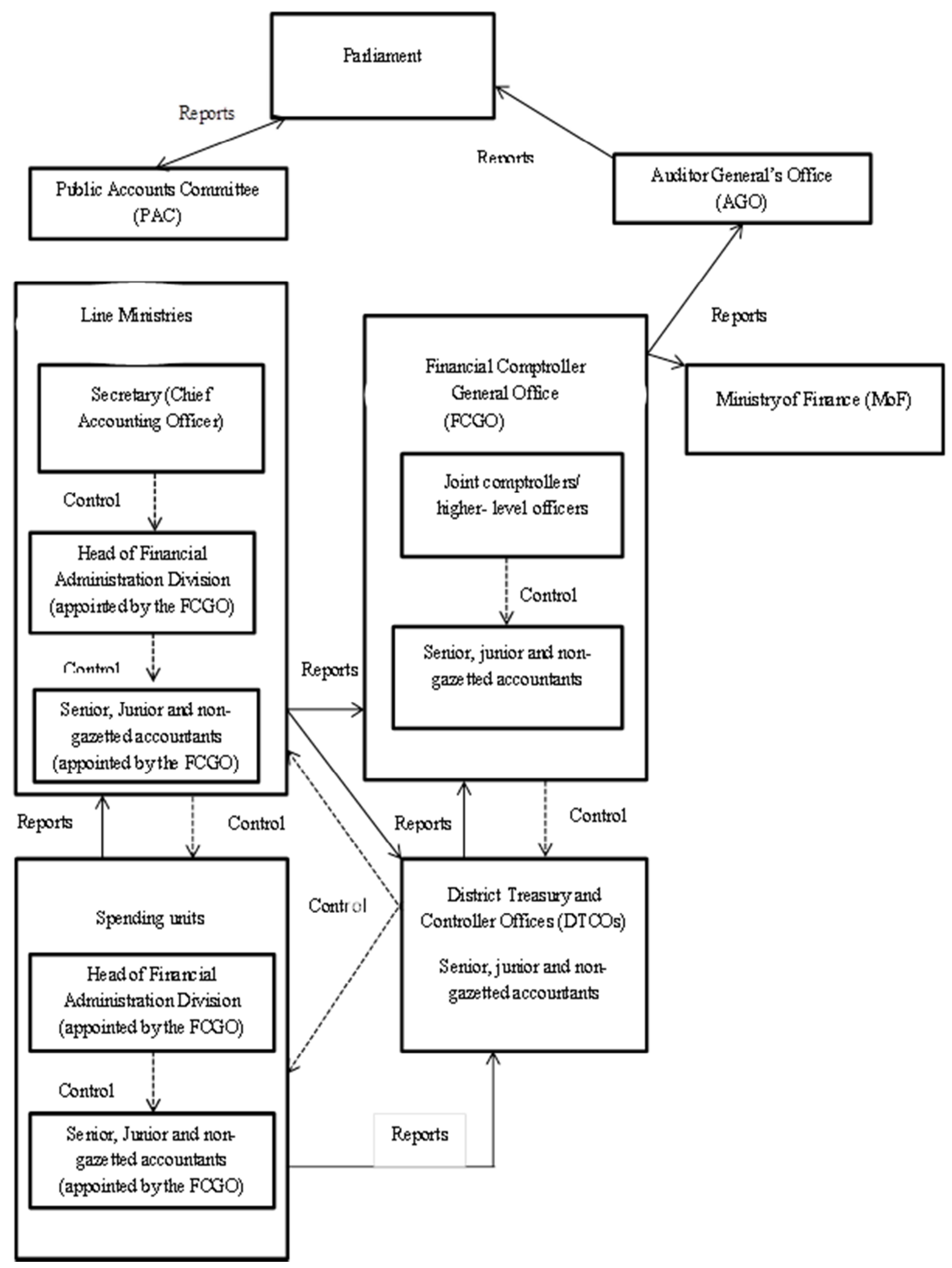

Similar to other emerging economies (Allen, 2009; Lassou and Hopper, 2016; Goddard et al., 2016), Nepal has been attempting to adopt the World Bank-led government accounting reforms since the 1980s (Adhikari \& Mellemvik, 2011). Accounting measures such as accrual accounting and programme budgeting were predicated during the initial years on the 
assumption that these measures would help the country improve planning and expenditure management and discharge wider accountability (World Bank, 2002; ADB, 2005; IMF, 2007). There is no evidence, however, that these reforms have proved successful (Adhikari et al., 2013). Since 2007, the World Bank has, however, prioritised the use of the Cash-Basis IPSAS before any move towards accrual accounting is undertaken (World Bank, 2007, 2010).

A number of efforts have been made in the last few years to embrace the Cash-Basis IPSAS within the Nepalese budgetary entities (ADB, 2011; World Bank, 2011). For instance, the Accounting Standards Board (ASB) - an independent institution to pronounce accounting standards for private enterprises - has been assigned with the task of developing a set of Nepal Public Sector Accounting Standards (NPSASs) that correspond to the Cash-Basis IPSAS. In addition, a separate unit, the Public Expenditure and Financial Accountability (PEFA), has been established within the FCGO to coordinate the implementation of public finance reforms, including the Cash-Basis IPSAS (ASB, 2009). More recently, the IPSAS project has been included in the multi-donor trust fund, chaired by the World Bank, as a priority project. The whole idea behind the trust is to consolidate the donors' fund into a single account and to use it in those projects/reforms that contribute to infrastructure development and governance changes. Despite such efforts, the implementation of the CashBasis IPSAS in budgetary entities has proved far more complex than first thought leading to a substantial delay in its adoption (MoF, 2012, 2014, 2015; FCGO, 2015). Similar to other emerging economies (Parry \& Wynne, 2009; World Bank, 2010; IFAC, 2010), there are several technical ambiguities envisaged in the implementation of the standard in budgetary entities; for instance, the preparation of full consolidation, the reporting of external assistance, and third-party payments. However, a key challenge in the adoption of the standard in Nepal has been to alter the routine behaviour and agency of government accountants and administrators, and to restructure the way in which the day-to-day accounting practice is taking shape (GoN, 2015).

\section{Empirical analysis and discussion}

This section, which is based on document analysis and semi-structured interviews, illustrates why and how central government accounting practice is reproduced in Nepal. At the outset, we demonstrate the structures of government accountants (the agents-in-focus), which shed light on the reasons for the reproduction of everyday government accounting practices. We 
have a particular focus on the agency and outcomes, areas in which there is envisaged a scope for the further extension of the SST (Feeney \& Pierce, 2016). We provide an in-depth analysis of the position-practice relations between government accountants and the agents-incontext, and delineate how these different agents with varied conduct and context are battling against others through the dialectic of control to maintain their interests, and how the day-today accounting practice is implicated in this process while resisting the proposed changes.

\subsection{Structures external to government accountants (the agents-in-focus)}

External structures, which involve position-practices and their networked relations, provide agents with a social identity with a range of prerogatives, capabilities, norms, resources, and obligations (Stones, 2005; Giddens, 1984). The social position of government accountants (the agents-in-focus) and their social identity are distinct in Nepal from other public administrators. Government accountants, who are organised and mobilised separately by the FCGO, have inherited a range of prerogatives and obligations relating to the articulation of financial/budget management and the discharging of accountability. We have in our study identified several clusters of actors who have position-practice relations with the agents-infocus (i.e. government accountants). These clusters of actors (the agents-in-context) include higher-level officers (first-class officers) at the FCGO and ministries, administrators, auditors at the Auditor General's Office, international consultants, politicians, and professional accountants at the Institute of Chartered Accountants of Nepal (ICAN) and the Accounting Standards Board (ASB). All of these actors have a stake in government accounting, although they hold different positions in their specific field and have varied prerogatives, obligations, and reactions with regard to budget and accounting changes. Figure 2 depicts the positionpractice relations of government accountants with these agents-in-context.

Figure 2: Position-practice relations in Nepalese central government accounting 


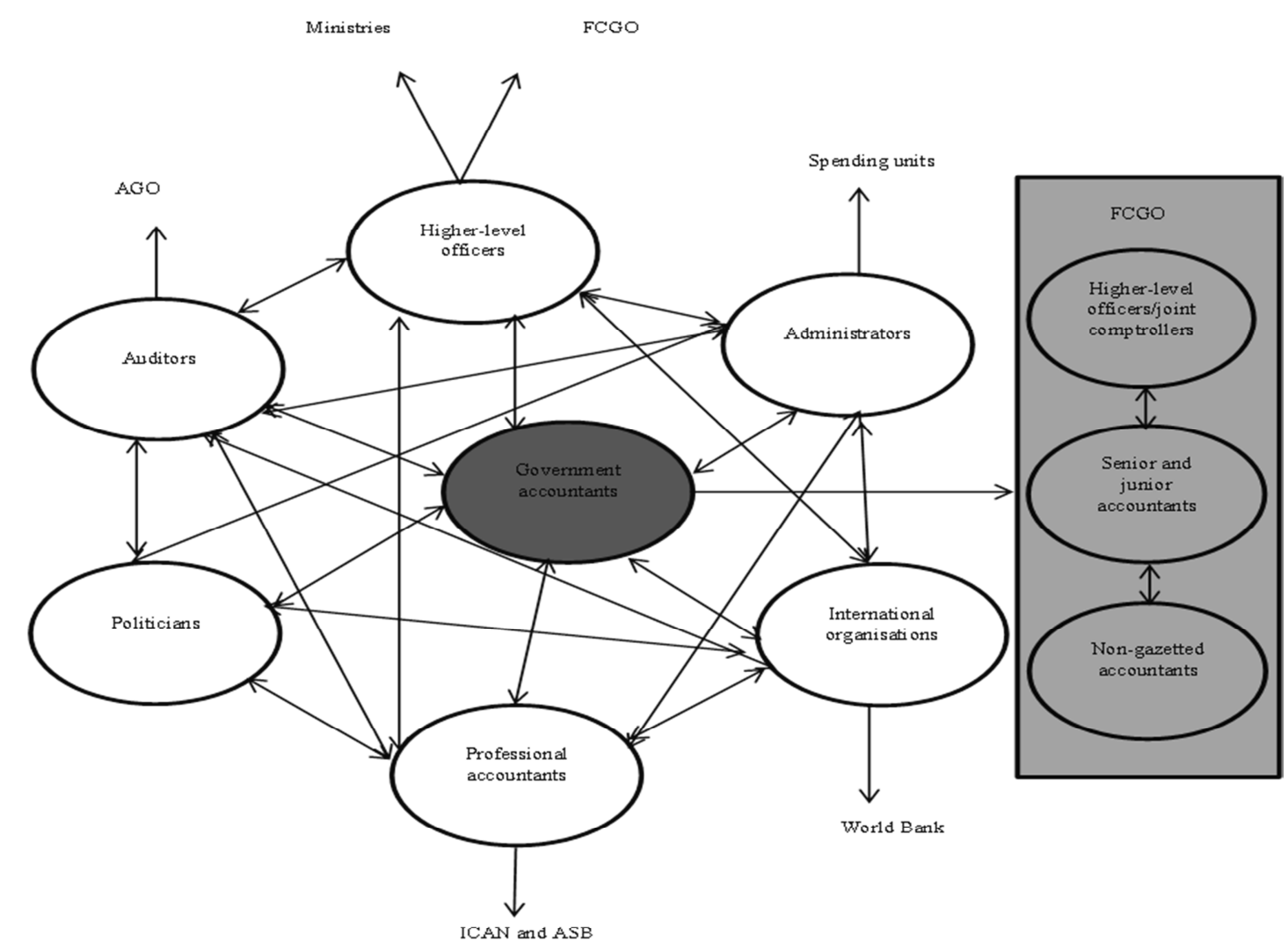

Altogether there are more than 5,000 government accountants under the jurisdiction of the FCGO, who are scattered across budgetary entities. In each ministry/department, a Financial Administration Division (FAD) exists, which is chaired by a senior accountant and consists of a cadre of junior and non-gazetted accountants. This division is seen more as a unit of the FCGO within the ministry. The fact that all financial and budget-related activities are facilitated through this division has led to a situation of resource or power asymmetries between this and other divisions within the ministry. This has often resulted in a hostile relationship between the FAD and other divisions, which is evident in the following statement of one senior accountant at the FCGO:

"We [the government accountants] feel treated like outsiders in the ministries. Often the ministerial decisions are made without involving representatives from the Financial Administration Division. We have budget information, so they are scared of us. We are told of the decisions only after they are approved, so that we would not be able to change them or to demonstrate obstacles in their implementation". 
Not only have the social positions provided the accountants with power asymmetries over resources (budget), but have on many occasions imposed a degree of constraints in their everyday work. The system of dual control imposed upon government accountants serves as an example (Agrawal \& Bista, 1981). Unlike the case of other administrators who are accountable to their concerned ministries, government accountants discharge their accountability, not only to the FCGO, but also to the Secretary of the ministry in which they are assigned to serve. The authority of the Secretary and the Financial Comptroller in regulating government accountants is explicitly codified in the 2007 Financial Administration Rules (FAR) (GoN, 2007). For instance, the Secretary is designated a 'Chief Accounting Officer' and is tasked with overseeing authority over financial operations within the respective ministry. In addition, the Secretary is required to undertake an annual performance appraisal of the head of the Financial Administration Division (FAD) and approve the appraisal of junior and non-gazetted accountants, which is the prerogative of the head of the FAD. Based on the regulations (GoN, 2007, 2008), such a performance appraisal, which takes place in the ministry, is supposed to provide the FCGO with a basis for deciding on the promotion, transfer, and capacity development of government accountants. Sharma (1996) states that this system of dual control introduced in the 1970s was actually meant to provide an additional safeguard to public money rather than to control government accountants. Over time, the system has become more a means of avoiding the accountants to exploit power or resource asymmetries, which they have inherited through their access to the budget. The following statement made by an administrator at the Ministry of Education (MoE) is evidence of the undermining of personal trust between government accountants and administrators evolved by their social position:

"If they [the accountants] do not release the allocated budget in a timely manner, we can approach the Secretary, who may consider this behaviour in their performance evaluation."

Social positions of government accountants have become a cause instigating power struggles between them and other administrators in everyday accounting. Government accountants' disposition and conjuncturally-specific knowledge of their strategic terrain and the conduct of the agents-in-context have however led them to become a dominant player in this power struggle within the network of relationships.

\subsection{Government accountants (the agents-in-focus) and internal structures}


Internal structures represent government accountants' (the agents-in-focus) general dispositions and the conjuncturally-specific understanding of their structural surroundings. The FCGO, since its establishment in 1974, has had a profound impact on the positionpractices of government accountants and setting up their dispositions and conjuncturallyspecific structures. Government accountants share similar socialisation processes and are adopting their practices based on the expected reactions of the agents-in-context, which mainly concern budget implementation and compliance. The budget has become an important tool and an established practice in the Nepalese public administration since the 1950s through which to articulate communication, exercise power, and impose sanctions. We observed during the interviews that a key benchmark when evaluating government accountants' performance has been their capability of realising the allocated budget to programmes and activities in a timely manner and of maintaining budgetary compliance. The majority of accountants mentioned that there are now broader and individual consequences if they fail to release or spend the allocated budget and maintain 'budgetary compliance'. A potential risk is that the Ministry of Finance may question the significance of an annual budget increment to their concerned ministry and undertake budget cuts. Underspending may also lead to an adverse consequence in the performance appraisal of accountants. A junior accountant at the Ministry of Federal Affairs and Local Development (MoFALD) remarked:

"The thing that is of concern to the Secretary and higher-level officers is not the results or outputs of public expenditure but spending the allocated money. If we fail to use the budget, it is likely that we will get less money next year. We may be labelled as being inefficient and ineffective in discharging our duty. Everyone will be impacted adversely. So we are morally responsible for helping us and the others to spend the allocated budget within a given time period."

The above statement is evidence that internal structures of Nepalese government accountants are shaped around the budget. As stated by Stones (2005), government accountants are aware of what the agents-in-context expect from them and the rewards and sanctions likely to follow from their actions. This understanding of government accountants has apparently become a factor which has led to many important provisions added into the accounting system/regulations in recent years becoming obsolete. For instance, there is a provision in the 2007 Financial Administration Rules (FAR) (see Chapter 3) which requires government entities to report certain accrual items such as outstanding staff advances and suppliers not being paid until the next year (GoN, 2007). We noted during our interviews that not only the 
non-gazetted and junior accountants, but also the senior accountants who are in charge of the Financial Administration Division are either unaware or neglecting the existing provisions of the accounting regulations. Their only concern has been to maintain the limits set out in the budget and discharge their accountability. A head of the FAD at the Ministry of Health $(\mathrm{MoH})$, who had the opportunity to attend a postgraduate programme in public sector accounting abroad, remarked:

"Our system is actually a modified cash accounting system. However, there is no demand for other statements apart from the budget reports. Our internal audit and external audits are all meant to ensure budgetary compliance. The vast majority of higher-level officers at the FCGO and the ministries are unaware that we are also required to maintain reports of assets and liabilities using the accounting form no. 18."

We have observed that Nepalese government accountants are both knowledgeable and reflexive in their day-to-day activities. They are capable of making use of their social position in reproducing budget routines (i.e. budget execution and compliance), applying various codes of interaction, amongst others, non-compliance and manipulation of budget information. They have maintained a general disposition to ignore or manipulate many accounting provisions other than those relating to budget release and compliance. We were told during our interviews that the manipulation of government accounting and budgeting information has become the taken-for-granted practice in Nepal. Indeed, there are several weaknesses inherited to the accounting system contributing to promoting this culture. For instance, a senior account officer at the Ministry of Federal Affairs and Local Development (MoFALD) remarked:

"The performance of the projects and programmes embedded in the medium-term budget has been subjective in terms of the lack of accounting information. Our accounting system is not detailed enough to delineate the progress that has been made towards achieving the intended results. We have to manipulate the costs and results in order to ensure compliance."

The existing high degree of 'trust' amongst government accountants due to their social position has however played an important role in the pursuit of such manipulative culture and disposition. Government accountants' conjuncturally-specific knowledge of the strategic terrain and in particular their ability to reflexively monitor the knowledge and social position of higher-level officers have further strengthened their capability to persist with this taken- 
for-granted manipulative practice (disposition). For instance, there is no such segregation amongst the administrators in the first class (higher-level) (PSC, 2007). This means when a senior accountant gets promoted, he/she will be automatically released from the accounting group and can be appointed as a higher-level officer in any ministry or department. Government accountants are aware of the fact that the majority of higher-level officers (firstclass officers) at the FCGO, who are assigned to scrutinise the ministerial statements, are from other disciplines than accounting and that they have limited knowledge of government accounting practices and of ongoing developments. This is evident in the following statement of a junior accountant serving at the FCGO:

"The new Joint Comptroller, I think he was from a revenue group, asked me to improve the system for recording advances in the MTEF projects, so as to make the transactions more transparent. I told him that transactions related to advances are not easy to categorise as they can be accommodated into five or six different budget items. He later gave up the idea and continued with the existing system."

We have also identified another factor, what Jayasinghe \& Thomas (2009) have described as a lack of fear about the potential consequences, impacting the government accountants' dispositions and conjuncturally-specific knowledge. As stated previously, over-politicisation has in recent years eroded a meritocracy in the Nepalese public administration (Dix, 2011). The issues such as promotion and transfer and reward and punishment of government accountants (as well as other administrators) are decided on the basis of "political connection and patronage' and other corrupt mechanisms rather than on the basis of the performance appraisal undertaken by the FCGO and concerned ministries. This has provided many politically-oriented but incompetent administrators/officers with an opportunity to get promoted to a higher position (Askvik, Jamil, \& Dhakal, 2010). A limited knowledge and understanding of government accounting has made these officers incapable of penalising their subordinates for any deviant practices, which has resulted in a situation of impunity (Ghimire, 2015). The manipulative culture is, however, seemingly widespread across all disciplines, not least in accounting and at all levels within the Nepalese public administration. Lacking capacity and competence, the higher-level officers therefore tend to establish a congenial relationship with junior staff members, and perpetuate their careers rather than jeopardise them by challenging them. Such is evident in the following statement of a junior accountant at the FCGO: 
"They [the higher-level officers] do not want conflicts with the accountants. They know that the accountants, if they wish, can make their life difficult by disapproving the payments and delaying the reporting. I know I won't be penalised for the manipulations of performance as long as I execute the allocated budget and maintain the accounts on a timely basis."

The above culture is envisaged as an addition to the bureaucratic tradition inherited from the history of Rana period, i.e. the shifting of personal responsibilities and the avoiding of decision-making (Dix, 2011). This reflects from the government accountants' judgments in everyday accounting practice. Government accountants are involved in dialogues with the agents-in-context to perpetuate the budget routine and resist the proposed changes. As stated by Jack \& Kholeif (2008), we have envisaged multiple dialectics of control in terms of resistance led to by the position-practice relations of accountants and the agents-in-context, which we will discuss in the next section.

\subsection{Active agency of government accountants (the agents-in-focus): contradictions and the dialectics of control in terms of resistance}

Active agency refers to those moments when the government accountants execute their everyday accounting practices and address reform ideas. It is seen as a result of a combination of government accountants' conduct and context analysis and the interaction between their external and internal structures (Stones, 2005). There are apparently contradictions between government accountants and the agents-in-context in the process of executing everyday accounting and implementing changes due to their different social positions and knowledge of structures. For instance, that the government accountants' day-today routines are confined to budget implementation implies that any proposed changes, which have a focus other than budget implementation, are likely to contradict with their conjuncturally-specific internal structures. On the contrary, the agents-in-context have turned out to be pro-reformists due to their position-practices emphasising the changes in existing accounting and the relevance of the Cash-Basis IPSAS. We have observed during our interviews that government accountants are, however, aware of these various positionpractice relations and the conduct and context of these networked agents-in-context, and that their social position has offered them perceived power (or capability) to dominate these actors-in-context in the duality and dialectic of control. Multiple dialectic of control relations 
have therefore been taking place in Nepalese central government accounting, which have resulted in the resistance to the externally-propagated changes.

5.3.1. Contradictions between government accountants and administrators/higher-level officers

The administrators and higher-level officers in the ministries and the FCGO are involved in executing the activities, programmes, and projects embedded in the budget, which they can carry on after the allocated budget is released to them from the Financial Administration Division (FAD). The position that they have inherited has exerted pressure on them to demonstrate the results and outcomes of budget expenditures, the realisation of which they argue would require the adoption of World Bank-propagated accounting discourses initiated at macro global level; for instance, the Cash-Basis IPSAS (Pradhan, 2013). Government accountants are therefore envisaged as a major obstacle in the articulation of these reforms. For instance, during our interviews, administrators and higher-level officers expressed their perceptions about government accountants and their interactions with them in implementing reforms. Not only are the accountants seen as outsiders in the ministry, the administrators and officers are of the view that they lack understanding of the bureaucratic procedures and the challenges involved in facilitating everyday administrative tasks. Implicit in the view of administrators and higher-level officers was the assertion that it is due to the hostile attitude of government accountants in embracing reforms that the problems of underspending, budget irregularities, and outstanding reimbursements have escalated in the country. An undersecretary at the MoF remarked:

"We have to show results, but we do not have control over the resources. The budget is in the possession of accountants, and they always find reasons to delay the release of the budget. They have no idea about the operation of administrative mechanisms. Changes in accounting should go on so that we do not need to rely upon their discretion for spending."

Generating resistance has been reckoned to be both the strategy of the accountants to continue making other administrators reliant on them for resources (i.e. the budget), and a way to ensure their ontological security (Giddens, 1979, 1984) by avoiding a threat to their prevailing budget routines. A higher-level officer at the Ministry of Finance justified why 
they exclude government accountants while undertaking a decision on issues relating to accounting reforms in the ministry at the meso level:

"In developing countries like Nepal, we first need to make reform decisions, and then only we can think of their implementation. If we start discussing with accountants, reforms will never be agreed. Government accountants are hostile to reforms, and if we start discussing with them whether we need reforms or not, agreement will never be reached."

We have observed that the government accountants are engaged, however, in the reflexive monitoring of position-practice relationships and conduct and context analysis in that they are aware of how the administrators and higher-level officers are likely to interpret their agency and intentions. First, they are aware of the fact that the higher-level officers and administrators, lacking basic accounting knowledge and understanding of the system, are mainly involved in negotiating with representatives of international organisations regarding the reforms. These officers are not familiar with the accounting problems that the government has encountered, are unaware of the available resources and infrastructure to instigate the World Bank-propagated reforms and lack an understanding of whether and how the adoption of reforms would lead to improvements in accounting practice. As a result, many government accountants have perceived that the implementation of reforms is nothing but just an additional burden to them. Commenting on the role of higher-level officers, a non-gazetted accountant at the FCGO stated:

“They [the higher-level officers] undertake decisions regarding many accounting issues and reforms without our consent and even without informing us. They do not know our requirements and capacity because they are not involved in the practice. We know that such reforms decided by the officers are not applicable in Nepal. What is the point of implementing these reforms then?"

Next, many government accountants are of the view that the higher-level officers and administrators are equally concerned over maintaining stability in cash accounting and the current way of operating the budget so as to maintain control over the accountants. As stated by Wildavsky (1972), mentions are made that the Nepalese administrators have always been reluctant to recognise accountants as financial managers, a designation which is specified in the regulations (GoN, 2007), and to delegate the authority and power allowing them to have a say in the selection of projects or programmes for the budget and the articulation of day-to- 
day public administration. Reforms such as the Cash-Basis IPSAS and accrual accounting, which call for more financial decision-making from accountants (Harun et al., 2012; Ashraf \& Uddin, 2013, 2015), are therefore more likely to pose a threat to the administrators. During our interviews, a large number of government accountants pointed out a range of activities that the administrators and higher-level officers have used to undermine the reform initiatives, including their denial to allocate extra budget for training and software development and a refusal to amend the regulations so as to make the use of the international standards mandatory, amongst other things. These activities are seen as indicators reflecting the actual intention of the higher-level officers and administrators, which is to give continuity to the budgetary tradition.

Implicit in the view of the government accountants was the assertion that the Cash-Basis IPSAS has proved to be a means for some higher-level officers and administrators at the Ministry of Finance and the FCGO to secure not only external legitimacy, but also additional benefits such as participation in training and seminars abroad. Such an attempt by higherlevel officers to personally exploit the benefits of World Bank-led reforms is evident also in other emerging economies (Uddin et al., 2011; Lassou \& Hopper, 2016). Some of the government accountants have envisaged this motive of the higher-level officers and administrators as a reason why junior and senior accountants are excluded from the reform process. A senior accountant at the FCGO remarked:

"Their [the higher-level officers and administrators] motive is just to impress international organisations and ensure their personal benefits. They accept any reforms proposed by international organisations. They also know that we [the accountants] would never accept any sort of reform that we could not achieve, such as accruals and accounting standards, so we are never invited to the meetings."

5.3.2. Contradictions between government accountants and professional accountants and international consultants

We observed that government accountants, however, have such dialectic contradictions, not only with the higher-level officers and administrators but also with professional accountants, some of whom were employed as an international consultants in the past, in terms of the need of reforms and the manner in which these changes should be articulated. For instance, they have been reflexively monitoring the World Bank's proposal of allowing the Accounting 
Standards Board (ASB) to develop public sector accounting standards, and an attempt by the professional accountants and international consultants to echo the voice of the World Bank with regard to the importance of the Cash-Basis IPSAS, for the sake of ensuring the Bank's financial support and justifying the expertise respectively. Government accountants are of the view that the Bank has forced the government to delegate the task of developing the Nepal Public Sector Accounting Standards corresponding to the Cash-Basis IPSAS to the ASB, which has neither any interest nor adequate concern over public sector accounting. The Bank's intention has been to implement the standards without undertaking any major amendments to the content. Professional accountants and their institutes are therefore best suited to fulfil this objective given their competence in handling technical accounting issues. Claims are made that the actual intention of professional accountants in pursuing the reforms has been to exert their domination in the public sector by overpowering government accountants and to ensure their personal gains rather than to improve the system. Such motives of professional accountants in public sector accounting are evident also in other contexts (Ashraf \& Uddin, 2013; Christensen, 2005). In commenting on the World Bank's involvement, a senior accountant at the FCGO stated:

“The World Bank should understand that government accounting is not the priority area of the ASB/ICAN. They just want to make the donors happy by forcing us to initiate reforms. In doing so, they would continue getting support in the name of implementing reforms. For instance, following the wishes of the Bank, the Board has altered a few of the wordings of the Cash-Basis IPSAS and handed it over to us for implementation. Had we been given the opportunity to develop the standards, we would have developed them in a way that represented our structure and requirements."

Similarly, government accountants are of the view that the consultants of the World Bank and other international organisations propagate reforms so as to demonstrate their expertise and promote the rhetoric of efficiency in resource allocation and management. A chartered accountant, however, who had previously worked as the World Bank's local consultant in financial management, denied the assertion stating:

"IPSAS can produce unique information about the performance of government policies, programmes, and projects. This information can be used to improve the management of public expenditures". 
During our interviews, the professional accountants also attempted to justify their actions by pointing to the attitude of government accountants and their conjuncturally-specific knowledge. The professional accountants are of the view that the bureaucratic mentality that the government accountants have institutionalised has eroded their innovativeness and adaptability to the new system, and that every actor propagating changes has appeared to them more as a threat. The Chairman of the ASB commented on the limited knowledge of government accountants and emphasised the involvement of chartered accountants in the reform process:

"I have been trying to tell government accountants that accounting standards (IPSASs) are meant to improve the reporting mechanisms rather than to overhaul the entire system. The FCGO has, however, envisaged standards similar to their accounting regulations. Without the participation of professional accountants, the government accountants would not be able to address any technical issues emerging from the implementation of the standards."

\subsubsection{Contradictions between government accountants and auditors}

In a similar vein, we noted during our interviews the prevalence of a duality and dialectic relationship between government accountants and auditors in implementing reforms. The auditors and the Auditor General's Office (AGO) have inherited a distinct social position, i.e. a constitutional unit in Nepal. The office is entitled to receive the budget directly from the Ministry of Finance without parliamentary scrutiny and approval, and has delegated an authority to summon any government officials for any perceived misuse of public resources. Public expectations of the AGO include the control of budget irregularities, the effective use of public resources, and the maintenance of financial discipline (AGO, 2012, 2014). The auditors during our interviews have made a claim that they have embarked on substantial changes in the auditing sector in recent years to meet such expectations, which include, amongst others, the introduction of performance-oriented reporting, the recruitment of professional accountants, and the capacity development of staff members. Government accountants have been reproached, however, for giving continuity to the compliance-oriented accounting and undermining the relevance of the changes which they have undertaken. A senior auditor at the AGO remarked: 
"Anyway, auditing comes after accounting. What is the point of introducing performance auditing when the focus of accounting is on compliance? The FCGO should not delay in embarking on the reforms."

As is the case with other actors-in-context, the reflexivity of government accountants is ostensible in maintaining the duality and dialogue with the auditors. The government accountants are strategically aware of the fact that despite the emphasis on performance and the results of public expenditures, the central focus of external auditing has been on detecting irregularities by examining whether or not the incurred expenditures are in accordance with the regulations. This is also evident in the annual audit reports issued by the AGO in which a greater emphasis has been placed on demonstrating the overall irregularities of the spending units and comparing them with previous years (AGO, 2012, 2014). The spending units' success in recovering and curtailing irregularities based on accounting statements has ostensibly become the yardstick through which to measure their efficiency and competence in budget management. The auditors are apparently more concerned over the stability of existing government accounting and budgetary routines so as to maintain their positonpractices with the government accountants. This is evident in the following statement made by a junior accountant at the FCGO:

"The auditors do know that reforms in accounting will weaken their influence because this will require them to focus on performance rather than irregularities or noncompliance, which they will not be able to cope with given the infrastructure and manpower they possess. The Auditor General's Office has not even approved our reporting formats based on IPSAS, and we cannot move on without their approval."

\subsubsection{Contradictions between government accountants and politicians}

The government accountants are of the view that such rhetoric for the need of accounting changes are common amongst the agents-in-context. In reality, government accounting reforms have been envisaged by these agents more as a means of granting accountants more autonomy (power asymmetries) over the budget, which is evident in the following statement of a senior accountant at the FCGO:

"They [the administrators and auditors] think accounting reforms will provide accountants with more power over resources and that they will be asked to report and 
audit the performance and results of previous expenditures. That is why it is very difficult for any accounting reform to get approval, even though everyone says accounting should be changed."

All above-mentioned discussions resemble the findings of prior work suggesting that the accounting system, which is likely to weaken the positions of certain actors, often engenders resistance (Scapens \& Roberts, 1993; Uddin \& Tsameny, 2005). However, what we have realised during our interviews, which differentiates Nepal from other western countries with regard to adopting accounting changes, is the support of government politicians. Studies of western countries have alluded to a lack of political will and support as a major impediment to the acceptance of government accounting reforms (Carlin, 2005; Guthrie, 1998; Hyndman \& Connolly, 2011). Although Nepalese government politicians (at ministerial level) have been reproached for their intervention in everyday accounting practice through promotions, transfers, and relocations of government accountants on the basis of political patronage and connection, the government accountants we interviewed claim that they have never been an obstacle to the acceptance of the proposed reforms at meso local level. The fact that they are concerned with gaining popularity within a short time span has led them to accept any change proposals without considering the pertinence of the changes, as well as the capacity of the country to accommodate such alterations. This attitude of government politicians has been claimed to be one reason why the country has been a pioneer in the context of emerging economies in adopting the World Bank-propagated reforms (Adhikari \& Mellemvik, 2011). The dialogue between the government politicians and the government accountants is evident in the following statement made by a senior accountant at the FCGO:

"I understand that government politicians are eager to declare reforms so as to garner public support. However, we are different because we need to go through all the procedures and regulations before adopting and implementing changes. It will not happen overnight as is wished by the politicians. If I were to adhere to what the politicians want, I would probably be accused of breaching the regulations. We have to refuse such politically oriented ideas."

\subsection{Outcomes}

Outcomes, which are the result of active agency, encapsulate the effect of agency on structures leading to the latter being altered, reproduced, or preserved. In our case, we 
observed that government accountants are under pressure to alter their day-to-day accounting practice and budget routines, and embrace proposed changes from higher-level officers, administrators, professional accountants, international consultants, auditors, and politicians. The very objectives and requirements of the proposed accounting measures, i.e. the CashBasis IPSAS and accrual accounting, which call for a greater role of accounting beyond maintaining budgetary compliance, have remained 'contradictory', however, with the agency and praxis of government accountants as well as other agents-in-context. Multiple dialectics of control therefore exist between government accountants and other actors, the ultimate outcome of which has been the resistance of reforms and the reproduction of traditional budget routines.

The progress achieved so far in implementing the Cash-Basis IPSAS adopted in 2009 perhaps serves as an illustration of the prevalence of such multiple dialectics of control in Nepalese government accounting. Despite the support of higher-level officers, administrators, professional accountants, auditors, consultants, and politicians, the adoption of the standard has not gone beyond its trial in some ministries in the last seven years, let alone been implemented across public entities in the country (FCGO, 2015; MoF, 2015). We argue that government accountants are dominating the position-power relations because of their capability in relation to other actors (i.e. power asymmetries in mobilising the budget), their trust between each other, and their knowledgeability in terms of the general dispositions and conjuncturally-specific knowledge of other actors. Through their conduct and context analysis of the agents-in-context, they know that all these pro-reformists in Nepalese government accounting are more concerned over either avoiding the delegation of additional authority to government accountants or ensuring the external resources (grants and aid). Propagating reforms has been their strategy to legitimise their position-practice relations. What they desire is to give continuity to the existing budget routines and to perpetuate their interest. Thus the case evidence has proved that at micro level the reforms have not been materialised, mainly because of the inability of the agents-in-context to make a considerable impact on the internal structures of the agents-in-focus (government accountants).

\section{Summary and conclusions}


We have in the paper illustrated why' and 'how' the routinised accounting practice is reproduced and the resistance to change is executed in the central government of Nepal. Nepal is often reckoned to be a front runner amongst emerging economies in terms of embracing the World Bank-led accounting discourses; for instance, accrual accounting and, more recently, the Cash-Basis IPSAS (Adhikari et al., 2013; Adhikari \& Mellemvik, 2011). However, the very objectives of accounting (i.e. budget execution and compliance) and its fundamental principle (i.e. the cash principle) have remained intact and the reforms adopted have become merely rhetoric. Status quo in practice and resistance to reforms characterise Nepalese central government accounting. The use of SST has enabled us to focus beyond institutional analysis - which has dominated the extant public sector accounting literature in Nepal and other emerging economies (Adhikari and Mellemvik, 2011; Adhikari et al., 2013; Harun et al., 2012) - to agency, and to empirically illustrate the duality and a dialectic relation between government accountants (the agents-in-focus) and the agents-in-context at different ontological scales in everyday accounting practice. We are not aware of any studies on public sector accounting in emerging economies which have offered such an in-depth analysis of interactions and agency between government accountants (the agents-in-focus) and the agents-in-context as led to by their external and internal structures and their conduct and context analysis.

In the paper, our first concern has been to unfold the reasons for the reproduction of routine government accounting practice at the ontic level. We have observed that significant differences exist between government accountants and the agents-in-context due to their position-practices. The position-practice relations of government accountants have been constructed by factors such as their formal separation from other bureaucrats and dual accountability being imposed on them. Their social position has led them to be perceived within a network of social relations as outsiders, and their identity has been constructed more as bookkeepers and budget compliers rather than financial advisors, an identity that the government accountants should hold according to the regulations (GoN, 2007). The separation from other groups has also offered possibilities to government accountants in that they are enabled to develop a high degree of trust and share similar dispositions and conjuncturally-specific knowledge amongst one other (Coad \& Glyptis, 2014; Coad \& Herbert, 2009; Moore \& McPhail, 2016). Moreover, the power over budget (allocative resources), which they have inherited due to social position have made them capable of dominating the agents-in-context in the network of relations. 
Our evidence has revealed that the general dispositions of government accountants have been confined to budget and its implementation. This is, however, not surprising given the fact that the main concern of Nepalese government accounting since its establishment in the 1960s has been to track budget expenditures, and that budget execution has continued to become a major issue/challenge in the country (Wildavsky, 1972; FCGO, 2015). Knowledge and capability are reckoned to be the two key sources, which enable the actors to reproduce their action (Stones, 2005). The findings of the study illustrate that government accountants are aware of the importance of executing budget and maintaining budgetary compliance given the knowledge of their social position and of the rewards and sanctions associated with spending the allocated budget. These internal structures are clearly reflected in their agency. They are also aware of the limited understanding of accounting amongst the higher-level officers and their incompetence in maintaining bureaucratic control due to political patronage. This knowledge has provided them with the opportunity to embrace various interpretative schemes; for instance, the non-compliance of those regulations not related to the budget and the manipulation of budget information, as part of perpetuating their day-today budget routines.

We have observed that the agency of Nepalese government accountants, as well as other agents, mainly the administrators and auditors (the agents-in-context), have continued to reflect the bureaucratic culture, which they had institutionalised during the Rana period; for instance, risk aversion and decision avoidance (Dix, 2011). Political patronage and connection have remained as the key determinants in the organisation of public administration. In addition, over-politicisation of public administration occurring in recent years has escalated impunity, which has demoralised government accountants in their day-today praxis, but at the same time offered them further capacity in activating their agency; for instance, pursuing various manipulative schemes without the fear of the potential consequences (Jayasinghe \& Thomas, 2009) and a greater strength in resisting changes.

Government accounting reforms proposed over time, such as accrual accounting and the Cash-Basis IPSAS, have therefore been denied because the very objectives of these reforms have contradicted the dispositions, conjuncturally-specific knowledge, and agency of government accountants and undermined their ontological security (Giddens, 1979, 1984; Stones, 2005). The fact that such externally-propagated reforms are premised on the rhetoric of augmenting efficiency and transparency in public expenditure management implies that 
they are not limited to executing the budget, a key concern of government accountants. The proposed reforms have posed government accountants a threat in the continuity of budget routines.

Our next concern in the study has been to investigate how the proposed government accounting changes are resisted. We have observed that although the higher-level officers, administrators, professional accountants, and auditors have acted as pro-reformists, government accountants are aware of their conjuncture and intentions through their conduct and context analysis, which range from controlling accountants to optimising organisational and personal benefits by impressing international organisations. Implicitly, some of these actors-in-context are more concerned over retaining the budget practices so as to ensure and maintain their existing position-practices and resources. This is evident in their day-to-day practice; for instance, the failure to sanction additional funds for facilitating training on the IPSAS (by higher-level officers and administrators) and denying the endorsement of the IPSAS forms and manuals (by auditors). The continuous reiteration of the need for reforms, however, has been their strategy to legitimise their position-practices. We argue that differences and contradictions between the clusters of agents have instigated duality and dialectic relationships between them. Multiple dialectics of control in terms of resistance are evident in Nepal, which have resulted in the reproduction of everyday government accounting practices and resistance to the World Bank-led reforms.

The extant literature in public sector reforms in emerging economies shows that resisting internationally-propagated reforms is not an easy endeavour in that such changes are often imposed to host countries as a precondition of financial and technical support (Neu et al., 2009; Neu \& Ocampo, 2007; Rahaman \& Lawrence, 2001). In addition, incentives and tangible benefits are offered to policy makers and higher-level officers in emerging economies for the acceptance of public sector accounting reforms (Uddin et al., 2011). This has resulted in some emerging economies in the abandonment of their well-functioning accounting and budgeting systems (Lassou and Hopper, 2016). Attempts of international organisations to disseminate neo-liberal reforms, which government accounting is part of, have therefore drawn critics, and questions have been raised as to what extent such reforms are optimal in the context of emerging economies (Lehman, 2005; Graham \& Neu, 2003; Stiglitz, 2000). We have in this paper offered further empirical evidence to support such critiques. Indeed, Nepal's political willingness to embrace the World Bank-led government 
accounting reforms may not be a surprise. However, what is striking in the context of Nepal is that the implementation of such reforms has been resisted at the ontic level by government accountants and the agents-in-context. Government accountants and the agents-in-context are blaming each other in their dialectic relations for the failure to implement the proposed changes, and in the process the stability in accounting practice has remained intact in the country.

We believe that Stones' (2005) SST has helped us enrich our understanding of central government accounting in Nepal, incorporating both the practices and changes. Our main empirical contribution in the paper has been an in-depth analysis of agency and structures in particular external structures - in everyday government accounting practice in emerging economies, issues that have been under-represented in the extant public sector accounting literature. We have offered an additional insight into why accounting reforms fail in the public sector of emerging economies and how actors in different position-practice relationships and at different levels of the ontological scale battle against others to resist such externally proposed changes. We argue that such a holistic understanding of government accounting practice and reforms at the ontic level in emerging and less-developed countries is paramount at present given that so much effort and resources, which could otherwise be used in other more important purposes, for instance, alleviating poverty, are being spent in the reconstruction of public sector accounting and accountability.

We have also addressed the call to apply ST in empirical accounting research (Englund and Gerdin, 2014; Makrygiannakis and Jack, 2016) and SST in the study of accounting in emerging economies and in the context of public sector (Jack \& Kholeif, 2008; Coad \& Glyptis, 2014; Elmassri et al., 2016; Feeney \& Pierce, 2016). More importantly, as emphasised in prior SST-based literature (Coad et al., 2015 and 2016), we have in this study moved beyond the static use of the quadripartite framework and further exploited the potential of SST by supplementing it with the ideas of conduct and context analysis and following its methodological prescriptions. This has helped us develop a further insight into the dialectics of control in terms of resistance. We have in this manner not only demonstrated the way SST can be applied in the empirical study of public sector accounting in emerging economies, but also contributed to extending the scope of SST for further research. 
To sum up, we would like to emphasis that public administration in most of the emerging and less-developed countries is centred on an annual budget (Allen, 2009), and government accountants hold a powerful position due to their role in executing budget and maintaining compliance. It is rather unlikely that any externally-propagated reforms would be implemented successfully in emerging economies without changing the emphasis on budget, and without a shift towards the agency of government accountants and other actors, which is also constructed on the day-to-day budgetary practices. The central government accounting in Nepal is just one illustration in this regard. The fact that emerging and less-developed countries have a unique historical and structural construction of active agency and government accounting practices (Alawattage et al., 2007) means that the use of social theories such as strong structuration in the study of public sector accounting in other emerging economies is of utmost importance. For instance, there is scope for further studies to unfold multiple dialectics of control as observed in the present study from the perspectives of the agents-in-context. This may not only assist day-to-day public sector accounting practices and ongoing reforms in emerging economies, but also to realise the full potential of strong structuration theory research in public sector accounting.

\section{References}

Accounting Standards Board (ASB). (2009). Nepal Public Sector Accounting Standard. Kathmandu: ASB.

Acharya, G. (2011). Central personnel agency: development, role and relevancy. The Nepalese Journal of Public Administration, 118(3), 206-214.

Adhikari, P., \& Mellemvik, F. (2009). Nepalese governmental accounting development in the 1950s and early 1960s: an attempt to institutionalize expenditure accounting. Accounting Historians Journal, 36(1), 112-33.

Adhikari, P., \& Mellemvik, F. (2011). The rise and fall of accruals: a case of Nepalese central government. Journal of Accounting in Emerging Economies, 1(2), 123-43.

Adhikari, P., Kuruppu, C., \& Matilal, S. (2013). Dissemination and institutionalization of public sector accounting reforms in less developed countries: a comparative study of the Nepalese and Sri Lankan central governments. Accounting Forum, 37(3), 213-230.

Agrawal, G., \& Bista, B. (1981). Government accounting in Nepal. Kathmandu: Centre for Economic Development and Administration, Tribhuvan University. 
Alawattage, C., Hooper, T., \& Wickramasinghe, D. (2007). Introduction to management accounting in less developed countries. Journal of Accounting \& Organizational Change, 3(3), 183-191.

Allen, R. (2009). The challenges of reforming budgetary institutions in developing countries (IMF working paper WP/09/96). Washington DC: Fiscal affairs department.

Andrews, M. (2012). The logical limits of best practice administrative solutions in developing countries. Public Administration and Development, 32(2), 137-153.

Ashraf, J., \& Uddin, S. (2013). A consulting giant; a disgruntled client: a 'failed' attempt to change management controls in a public sector organisation. Financial Accountability \& Management, 29(2), 186-205.

Ashraf, J., \& Uddin, S. (2015). New public management, cost savings and regressive effects: a case from a less developed country. Critical Perspectives on Accounting, http://dx.doi.org/10.1016/j.cpa.2015.07.002 (in press).

Askvik, S., Jamil, I., \& Dhakal, T. (2010). Citizens' trust in public and political institutions in Nepal. International Political Science Review, XX(X), 1-21.

Asian Development Bank (ADB). (2005). Nepal public finance management assessment. Manila: ADB.

Asian Development Bank (ADB). (2011). Nepal country operations business plan. Manila: ADB.

Auditor General's Office (AGO). (2012). Fiftieth (50th) annual report of the Auditor General. Kathmandu: AGO.

Auditor General's Office (AGO). (2014). Fifty-first (51st) annual report of the Auditor General. Kathmandu: AGO.

Carlin, T. (2005). Debating the impact of accrual accounting and reporting in the public sector. Financial Accountability \& Management, 21(3), 309-36.

Chatterjee, R. (1967). Report on the accounting system in Nepal. Kathmandu: MoF.

Christensen, M. (2005). The 'third hand': private sector consultants in public sector accounting change. European Accounting Review, 14(3), 447-474.

Coad, A., \& Glyptis, L. (2014). Structuration: a position-practice perspective and an illustrative study. Critical Perspectives on Accounting, 25(2), 142-161.

Coad, A., \& Herbert, I. (2009). Back to the future: new potential for structuration theory in management accounting research? Management Accounting Research, 20(3), 177-192. 
Coad, A., Jack, L., \& Kholeif, A. (2015). Structuration theory: reflections on its further potential for management accounting research. Qualitative Research in Accounting \& Management, 12(2), 153-171.

Coad, A., Jack, L., \& Kholeif, A. (2016). Strong structuration theory in accounting research. Accounting, Auditing \& Accountability Journal, 29(7), 1138 - 1144

Cohen, I.J. (1989). Structuration theory: Anthony Giddens and the constitution of social life. London: Macmillan.

Conrad, L. (2005). A structuration analysis of accounting systems and systems of accountability in the privatised gas industry. Critical Perspectives on Accounting, 16(1), 126.

Dhakal, T. (2007). Challenges of civil society governance in Nepal. JOAAG, 2(1), 61-73.

Dix, S. (2011). Corruption and anti-corruption in Nepal: lessons learned and possible future initiatives (NORAD Report 18/11 Discussion). Kathmandu: NORAD.

Elmassri, M., Harris, E., \& Carter, D. (2016). Accounting for strategic investment decisionmaking under extreme uncertainty. The British Accounting Review, 48(2), 151-168.

Englund, H., Gerdin J., \& Burns, J. (2011). 25 years of Giddens in accounting research: achievements, limitations and the future. Accounting, Organizations and Society, 36(8), 494513.

Englund, H., \& Gerdin, J. (2014). Structuration theory in accounting research: applications and applicability. Critical Perspectives on Accounting, 25(2), 162-180.

Feeney, O., \& Pierce, B. (2016). Strong structuration theory and accounting information: an empirical study. Accounting, Auditing \& Accountability Journal, 29(7), 1152-1176.

Financial Comptroller General Office (FCGO). (2015). Government of Nepal: consolidated financial statement of fiscal year 2013/2014. Kathmandu: FCGO.

Ghimire, D. (2015). Impunity and corruption. Transparency International Nepal Bulletin (Paaradarshi), 15(1), 79-80.

Giddens, A. (1979). Central problems in social theory: action, structure and contradictions in social analysis. London: Macmillan Press.

Giddens A. (1984). The constitution of society. Cambridge, MA: Polity Press.

Goddard, A., Assad, M., Issa, S., Malagila, J., \& Mkasiwa, T. (2016). The two publics and institutional theory - A study of public sector accounting in Tanzania. Critical Perspectives on Accounting, 40(October), 8-25.

Government of Nepal (GoN). (1999). The financial procedures act (FPA). Kathmandu: Law Commission. 
Government of Nepal (GoN). (2007). Financial administration rules (FAR). Kathmandu: Law Commission.

Government of Nepal (GoN). (2008). An assessment of the public financial management performance measurement framework (as of fy 2005/06). Kathmandu: FCGO.

Government of Nepal (GoN). (2011). 1993 Civil service rules (with third amendments of 2011). Kathmandu: Law Commission.

Government of Nepal (GoN). (2015). Public expenditure and financial accountability (PEFA) assessment. Kathmandu: FCGO.

Gongal, S. (1973). Occasional paper no. 4: foreign experts in the administration of Nepal. Kathmandu: TU Campus.

Goodall, M. (1963). Development of public administration in Nepal: final report to the government of Nepal. Kathmandu: GoN.

Goodall, M. (1975). Bureaucracy and bureaucrats: some themes drawn from the Nepal experience. Asian Survey, 15(10), 892-895.

Graham, C., \& Neu, D. (2003). Accounting for globalisation. Accounting Forum, 27(4), 449471.

Greenhalgh, T., \& Stones, R. (2010). Theorising big IT programs in healthcare: strong structuration theory meets actor-network theory. Social Science \& Medicine, 70(9), 12851294.

Greenhalgh, T., Stones, R., \& Swinglehurst, D. (2014) Choose and book: A sociological analysis of 'resistance' to an expert system. Social Science \& Medicine, 104(March), 210219.

Guthrie, G. (1998). Application of accrual accounting in the Australian public sector Rhetoric or reality. Financial Accountability \& Management, 14(1), 1-19.

Guthrie, J., Olson, O., \& Humphrey, C. (1999). Debating developments in new public financial management: the limits of global theorising and some new ways forward. Financial Accountability \& Management, 15(3/4), 209-228.

Hachhethu, K. (2009). State building in Nepal: creating a functional state. Kathmandu: Enabling State Programme.

Harris, E., Northcott, D., Elmassri, M., \& Huikku, J. (2016). Theorising strategic investment decision-making using strong structuration theory. Accounting, Auditing \& Accountability Journal, 29(7), 1177-1203.

Harun, H., Peursen, K., \& Eggleton, I. (2012). Institutionalization of accrual accounting in Indonesian public sector. Journal of Accounting \& Organizational Change, 8(3), 257-285. 
Hood, C. (1995). The "new public management" in the 1980s: variations on a theme. Accounting, Organizations and Society, 20(2/3), 93-109.

Hopper, T., Lassou, P., \& Soobaroyen, T. (2016). Globalisation, accounting and developing countries, Critical Perspectives on Accounting, http://dx.doi.org/10.1016/j.cpa.2016.06.003 (in press).

Hyndman, N., \& Connolly, C. (2011). Accruals accounting in the public sector: a road not always taken. Management Accounting Research, 22(1), 36-45.

International Federation of Accountants (IFAC). (2010). Review of the cash-basis IPSAS: report of the task force (agenda paper 6.1). Vienna: IFAC.

International Monetary Fund (IMF). (2007). Nepal: report on observance of standards and codes-fiscal transparency module (country report no. 07/346).Washington, DC: IMF.

Jack, L., \& Kholeif, A. (2007). Introducing strong structuration theory for informing case studies in accounting, organisation and management. Qualitative Research in Organizations and Management, 2(3), 208-225.

Jack, L., \& Kholeif, A. (2008). Enterprise resource planning and a contest to limit the role of management accountants: a strong structuration perspective. Accounting Forum, 32(1), 3045 .

Jayasinghe, K., \& Thomas, D. (2009). The preservation of indigenous accounting systems in a subaltern community. Accounting, Auditing \& Accountability Journal, 22(3), 351-378.

Joshi, N. (1973). Evolution of public administration in Nepal, experiences and lessons. Kathmandu: CEDA.

King, G., Murray, C., Salomon, J., \& Tandon, A. (2004). Enhancing the validity and crosscultural comparability of measurement in survey research. American Political Science Review, 98(1), 191-207.

Kuruppu, C., Adhikari, P., Gunarathna, V., Ambalangodage, D., Perera, P., \& Karunarathna, C. (2016). Participatory budgeting in a Sri Lankan urban council: a practice of power and domination. Critical Perspectives on Accounting, http://dx.doi.org/10.1016/j.cpa.2016.01.002 (in Press).

Lassou, P., \& Hopper, T. (2016). Government accounting reform in an ex-French African colony: the political economy of neo-colonialism. Critical Perspectives on Accounting, 36 (April), 39-57.

Lawrence, S., Alam, M., Northcott, D., \& Lowe, T. (1997). Accounting systems and systems of accountability in the New Zealand health sector. Accounting, Auditing \& Accountability Journal, 10(5), 665-683. 
Lehman, G. (2005). A critical perspective on the harmonisation of accounting of accounting in a globalising world. Critical Perspectives on Accounting, 16(7), 975-992.

Makrygiannakis, G., \& Jack, L. (2016). Understanding management accounting change using strong structuration frameworks. Accounting, Auditing \& Accountability Journal, 29(7), 1234-1258.

Ministry of Finance (MoF). (2012). Portfolio performance for development results: Nepal portfolio performance review. Kathmandu: GoA.

Ministry of Finance (MoF). (2014). Nepal portfolio performance review. Kathmandu: GoN.

Ministry of Finance (MoF). (2015). Nepal portfolio performance review (NPPR).

Kathmandu: GoN.

Moore, D. (2013). Sustainability, institutionalization and the duality of structure: contradiction and unintended consequences in the political context of an Australian water business. Management Accounting Research, 24(4), 366-386.

Moore, D., \& McPhail, K. (2016). Strong structuration and carbon accounting: a positionpractice perspective of policy development at the macro, industry and organizational levels. Accounting, Auditing \& Accountability Journal, 29(7), 1204-1233

Neu, D., \& Ocampo, E. (2007). Doing missionary work: the World Bank and the diffusion of financial practices. Critical Perspectives on Accounting, 18(3), 63-89.

Neu, D., Everett, J., \& Rahaman, A.S. (2009). Accounting assemblages, desire, and the body without organs: a case study of international development lending in Latin America. Accounting Auditing \& Accountability Journal, 22(3), 319-50.

Nor-Aziah, A., \& Scapens, R. (2007). Corporatisation and accounting change: the role of accounting and accountants in a Malaysian public utility. Management Accounting Research, 18(2), 209-247.

Parry, M., \& Wynne, A. (2009). The cash basis IPSAS: an alternative view. International Journal on Governmental Financial Management, 9(2), 2329.

Pokharel, K. (2011). De-politicizing Nepal's bureaucracy: the road to bureaucratic stability. The Nepalese Journal of Public Administration, 117(2),120-126.

Pokharel, K. (2013). New public management and its significance in Nepalese public administration. The Nepalese Journal of Public Administration, 124(3), 130-137.

Pozzebon, M., \& Pinsonneault, A. (2005). Challenges in conducting empirical work using structuration theory: learning from IT research. Organization Studies, 26(9), 1353-1376.

Powson, R., Tilley, N. (1997). Realistic Evaluation. London: Sage Publications. 
Pradhan, S. (2013). Budgetary reform: implementing medium term budgeting framework (MTBF) in Nepal. The Nepalese Journal of Pubic Financial Management, 2(1), 1-10.

Public Service Commission (PSC). (2007). Issues on public service commission. Kathmandu: PSC.

Rahaman, A.S. (2010). Critical accounting research in Africa: whence and whither. Critical Perspectives on Accounting, 21(5), 420-27.

Rahaman, A.S., \& Lawrence, S. (2001). Public sector accounting and financial management in a developing country organisational context: a three-dimensional view. Accounting Forum, 25(2), 189-210.

Rose, L., \& Landau, M. (1977). Bureaucratic politics and development in Nepal. In B.N. Pandey (Ed.), Leadership in South Asia. New Delhi: Vikas Publishing House.

Scapens, R., \& Roberts, J. (1993). Accounting and control: a case study of resistance to accounting and change. Management Accounting Research, 4(1), 1-32.

Seal, W., \& Ball, A. (2011). Interpreting the dynamics of public sector budgeting: a dialectic of control approach, Financial Accountability \& Management, 27(4), 409-436.

Shakya, R. (2009). "Why civil service reforms fail? - a case of Nepal. Administration and Management Review, 21(2), 40-63.

Sharma, S.P. (1996). The financial comptroller general office and financial information system (Maha Lekha Karlaya ra Bitya Shuchan Parnali). The Nepalese Journal of Public Finance and Development, 16(2), 53-9.

Sharma, R. (2002). The formulation, implementation and presentation of accounting policies: problems and possibilities (Lekhankan niti ko tarjuma karnayayan ra prusutikiran: samasya ra sambahvana). Journal of Public Finance and Development, 23(2), 31-38.

Shrestha, M. (1965). A handbook of public administration in Nepal. Kathmandu: HMGN.

Stiglitz, J. (2000). Globlization and its discontents. New York: W.W. Norton.

Stones, R. (2005). Structuration Theory. Basingstoke: Palgrave Macmillan.

Stones, R., \& Jack, L. (2016). The bridge between ontological concepts and empirical evidence: an interview with Rob Stones. Accounting, Auditing \& Accountability Journal, 29(7), 1145-1151.

Uddin, S., Gumb, B., \& Kasumba, S. (2011). Trying to operationalize typologies of the spectacle: a literature review and a case study. Accounting, Auditing \& Accountability Journal, 24(3), 288-14. 
Uddin, S., \& Tsamenyi, M. (2005). Public sector reforms and the public interest: a case study of accounting control changes and performance monitoring in a Ghanaian state-owned enterprise. Accounting, Auditing \& Accountability Journal, 18(5), 648-74.

Van Helden, J., \& Ouda, H. (2016). Public sector accounting in emerging economies. Critical Perspectives on Accounting, 40(October), 1-7.

Van Helden, J., \& Uddin, S. (2016). Public sector management accounting in emerging economies: a literature review. Critical Perspectives on Accounting, http://dx.doi.org/10.1016/j.cpa.2016.01.001 (in press).

Verma, S., \& Gray, S. (2009). The development of company law in India: the case of the Companies Act 1956. Critical Perspectives on Accounting, 20(1), 110-135.

Wijewardena, H., \& Yapa, S. (1998). Colonialism and accounting education in developing countries: the experiences of Singapore and Sri Lanka. The International Journal of Accounting, 33(2), 269-281.

Wildavsky, A. (1972). Why planning fails in Nepal. Administrative Science Quarterly, 17(4), 508-28.

World Bank. (2002). Financial accountability in Nepal: a country assessment. Washington DC: World Bank.

World Bank. (2007). Nepal public sector accounting and auditing: a comparison of international standards. Washington DC: World Bank.

World Bank. (2010). Public sector accounting and auditing in South Asia (report no. 54606$S A S)$. Washington DC: South Asia Region Financial Management Unit.

World Bank. (2011). Project paper on a proposed grant out of Nepal public financial management (PFM) multi donor trust fund (MDTF). Washington DC: Financial Management Unit, South Asia Region.

Yapa, P., Jacobs, K., \& Huot, B. (2016). The field of accounting: exploring the presence and absence of accounting in Cambodia. Accounting, Auditing \& Accountability Journal, 29(3), 401-427. 
Appendix A. Distribution of our interviewees

\begin{tabular}{|c|c|c|c|c|}
\hline Interviewees & $\begin{array}{l}\text { Position of } \\
\text { interviewees }\end{array}$ & Interviewees' offices & $\begin{array}{l}\text { March/April } \\
2014\end{array}$ & $\begin{array}{l}\text { August } \\
2015\end{array}$ \\
\hline $\begin{array}{l}\text { Joint } \\
\text { comptrollers } \\
\text { and joint } \\
\text { secretaries }\end{array}$ & $\begin{array}{l}\text { First-class or } \\
\text { Higher-level } \\
\text { officers/admini } \\
\text { strators }\end{array}$ & $\begin{array}{l}\text { The Financial Comptroller } \\
\text { General Office (FCGO) and } \\
\text { different ministries (mainly } \\
\text { the Ministry of Health } \\
(\mathrm{MoH}) \text {, the Ministry of } \\
\text { Finance (MoF), the Ministry } \\
\text { of Education (MoE), and the } \\
\text { Ministry of Federal Affairs } \\
\text { and Local Development } \\
\text { (MoFALD) }\end{array}$ & 4 & \\
\hline $\begin{array}{l}\text { Senior and } \\
\text { junior } \\
\text { government } \\
\text { accountants }\end{array}$ & $\begin{array}{l}\text { Gazetted or } \\
\text { officer-level } \\
\text { government } \\
\text { accountants }\end{array}$ & $\begin{array}{l}\text { The FCGO, the District } \\
\text { Treasury and Controller } \\
\text { Offices (DTCOs), and the } \\
\text { Financial Administration } \\
\text { Division (FAD) (within the } \\
\text { MoF, the MoH, the MoE, and } \\
\text { the MoFALD) }\end{array}$ & 14 & 4 \\
\hline $\begin{array}{l}\text { First, second, } \\
\text { third, and } \\
\text { fourth class } \\
\text { government } \\
\text { accountants }\end{array}$ & $\begin{array}{l}\text { Non-gazetted } \\
\text { or non-officer } \\
\text { level } \\
\text { government } \\
\text { accountants }\end{array}$ & $\begin{array}{l}\text { The FCGO, the DTCOs, and } \\
\text { the FAD (within the MoF, the } \\
\text { MoH, the MoE, and the } \\
\text { MoFALD) }\end{array}$ & 5 & 1 \\
\hline Officers & $\begin{array}{l}\text { Administrators } \\
\text { /under- } \\
\text { secretaries/bur } \\
\text { eaucrats }\end{array}$ & $\begin{array}{l}\text { The MoF, the MoH, the } \\
\text { MoE, and the MoFALD }\end{array}$ & 10 & \\
\hline Auditors & $\begin{array}{l}\text { Senior and } \\
\text { junior auditors }\end{array}$ & $\begin{array}{l}\text { Auditor General's Office } \\
\text { (AGO) }\end{array}$ & 4 & \\
\hline $\begin{array}{l}\text { Professional } \\
\text { accountants } \\
\text { and } \\
\text { international } \\
\text { consultants }\end{array}$ & $\begin{array}{l}\text { Chartered } \\
\text { accountants } \\
(\mathrm{CA})\end{array}$ & $\begin{array}{l}\text { The Institute of Chartered } \\
\text { Accountants of Nepal (ICAN) } \\
\text { and the Accounting Standards } \\
\text { Board (ASB) }\end{array}$ & $\begin{array}{l}3 \text { (Two of the } \\
\text { interviewed CA } \\
\text { had previously } \\
\text { worked as a } \\
\text { consultant for } \\
\text { the World Bank } \\
\text { and the Asian } \\
\text { Development } \\
\text { Bank in their } \\
\text { public finance } \\
\text { reform projects }\end{array}$ & \\
\hline
\end{tabular}

